\title{
Sistem Pengendalian Internal, Sistem Akuntansi Instansi, Kompetensi Sumber Daya Manusia dan Kualitas Laporan Keuangan di Kementerian Agama Propinsi Banten
}

\author{
Fitri Akbariah $^{1}$, Suratno ${ }^{2}$ \\ 1.2 Universitas Pancasila, Jl. Srengseng Sawah, Jagakarsa, Jakarta Selatan, 12640
}

INFO ARTIKEL

JEL Classsification:

M40

$J 24$

Keywords:

financial statements

quality, internal

control system,

instance accountancy

system, and human

resources competence.

\begin{abstract}
This study analyses the effect between internal control system, instance accountancy system, and human resources competence toward financial statements quality in Banten Province Ministry Religious Affairs. The data were collected from questioners that had been answered by 95 respondents in Banten Province Ministry Religious Affairs. Data analyzing technique uses multiple regression analysis. The result finds internal control system, instance accountancy system, and human resources competence significantly effected toward financial statements quality in banten province ministry religious affairs.
\end{abstract}

\begin{abstract}
ABSTRAK
Tujuan penelitian ini adalah untuk menganalisis pengaruh antara sistem pengendalian internal, sistem akuntansi instansi dan kompetensi sumber daya manusia terhadap kualitas laporan keuangan di Kementerian Agama Provinsi Banten. Data dalam penelitian diperoleh dengan menggunakan kuesioner yang diisi oleh 95 orang responden di Kementerian Agama Provinsi Banten. Teknis analisa data menggunakan analisis regresi berganda. Hasil penelitian menunjukkan bahwa sistem pengendalian internal, sistem akuntansi instansi dan kompetensi sumber daya manusia berpengaruh signifikan terhadap kualitas laporan keuangan di Kementerian Agama Provinsi Banten.
\end{abstract}

\section{Pendahuluan}

Organisasi sektor publik di Indonesia dalam praktiknya kini diwarnai dengan munculnya fenomena menguatnya tuntutan akuntabilitas atas organisasi-organisasi publik tersebut, baik di pusat maupun daerah. Akuntabilitas merupakan bentuk kewajiban mempertanggungjawabkan keberhasilan atau kegagalan pelaksanaan misi organisasi dalam mencapai tujuan dan sasaran yang telah ditetapkan sebelumnya, melalui suatu media pertanggungjawaban yang dilaksanakan secara periodik yang disebut dengan laporan keuangan (Mardiasmo, 2006). Laporan keungan merupakan posisi keuangan penting yang berasal dari transaksi-transaksi yang dilakukan oleh organisasi sektor publik dan merupakan media sebuah entitas untuk mempertanggungjawabkan aktivitasnya kepada publik selain itu juga berfungsi untuk memberikan informasi dalam pengambilan keputusan dan evaluasi kinerja kepemerintahan, maka dari itu informasi yang

*Email Korespondensi: ${ }^{1}$ supernova_nurlam@yahoo.co.id, ${ }^{2}$ suratno@univpancasila.ac.id 
disajikan harus memiliki nilai, agar informasi keuangan tersebut dapat bermanfaat bagi para penggunanya. Sebuah laporan yang memiliki nilai sehingga bermanfaat bagi penggunanya menandakan laporan keuangan tersebut berkualitas, dalam hal ini laporan keuangan haruslah memenuhi prinsip-prinsip tepat waktu dan disusun sesuai dengan Standar Akuntansi Pemerintah (SAP), yang merupakan salah satu aspek penting yang diperlukan untuk meningkatkan kualitas laporan keuangan.

Sebagai salah satu bentuk pertanggungjawaban dalam penyelenggaraan pemerintahan yang diatur dalam UndangUndang (UU) Nomor 17 Tahun 2003 tentang Keuangan Negara dan UU Nomor 32 Tahun 2004 tentang Pemerintahan Daerah. Upaya konkrit untuk mewujudkan transparansi dan akuntabilitas pengelolaan keuangan pemerintah, baik pemerintah pusat maupun pemerintah daerah adalah dengan menyampaikan laporan pertanggungjawaban berupa laporan keuangan.

SAP menyebutkan bahwa karakteristik kualitatif laporan keuangan adalah ukuranukuran normatif yang perlu diwujudkan dalam informasi akuntansi sehingga dapat memenuhi tujuannya. Keempat karakteristik berikut ini merupakan prasyarat normatif yang diperlukan agar laporan keuangan pemerintah dapat memenuhi kualitas yang dikehendaki, yakni:

a) Relevan, yang berarti informasi harus memiliki feedback value, predictive value, tepat waktu dan lengkap

b) Andal, yang berarti informasi harus memiliki karakteristik penyajian jujur, variabilitas, netralitas

c) Dapat dibandingkan, berarti laporan keuangan dapat dibandingkan dengan periode sebelumnya atau dibandingkan dengan laporan keuangan entitas lain.

d) Dapat dipahami, berarti bahwa informasi yang disajikan dalam laporan keuangan dapat dipahami oleh pengguna dan dinyatakan dalam bentuk serta istilah yang disesuaikan dengan batas pemahaman para pengguna.

Pengembangan sistem memerlukan suatu perencanaan dan pengimplementasian yang hati-hati, untuk menghindari adanya penolakan terhadap sistem yang dikembangkan. Suatu keberhasilan implementasi sistem tidak hanya ditentukan pada penguasaan teknis belaka, namun banyak penelitian menunjukkan bahwa faktor perilaku dari individu pengguna sistem sangat menentukan kesuksesan implementasi (George \& Hopword, 1995).

Selain itu, hal yang mendasar dan penting dari penerapan Akuntansi di dalam penyusunan Laporan Keuangan Instansi salah satunya adalah Sistem Akuntansi. Sebagaiman pengertian dari Sistem Akuntansi Keuangan Daerah yaitu serangkaian prosedur mulai dari proses pengumpulan data, pencatatan, pengikhtisaran, sampai dengan pelaporan keuangan, dalam rangka pertanggungjawaban pelaksanaan APBN yang dapat dilakukan secara manual atau menggunakan aplikasi komputer (Permendagri No. 59 Tahun 2007).

Laporan Keuangan Pemerintah Pusat (LKPP) setiap tahunnya mendapat penilaian berupa Opini dari Badan Pengawas Keuangan (BPK). Ketika BPK memberikan Opini Wajar Tanpa Pengecualian (WTP) terhadap Laporan Keuangan Pemerintah Daerah (LKPD), artinya dapat dikatakan bahwa Laporan Keuangan suatu entitas pemerintah daerah tersebut disajikan dan diungkapkan secara wajar dan berkualitas. Terdapat empat opini yang diberikan pemeriksa yaitu: Opini Wajar Tanpa Pengecualian (WTP), Opini Wajar Dengan Pengecualian (WDP), Opini Tidak Wajar (TP), dan Pernyataan Menolak memberi Opini atau Tidak Memberi Pendapat (TMP).

Audit yang dilakukan oleh BPK-RI atas LKPP selama 5 tahun terakhir (2011, 2012, 2013, 2014 dan 2015) opini audit Kementerian Agama yaitu: 
Tabel 1. Hasil Opini Audit Kementerian Agama, RI.

\begin{tabular}{cccccccr}
\hline NO & BA & KEMENTERIAN/ & \multicolumn{4}{c}{ OPINI BPK ATAS KKL } \\
& & LEMBAGA & 2011 & 2012 & 2013 & 2014 & 2015 \\
\hline 1 & 025 & Kementerian Agama & WTP-DPP & WTP-DPP & WTP-DPP & WTP-DPP & WDP \\
\hline
\end{tabular}

Sumber Laporan Hasil Pemeriksaan BPK RI

Dalam melakukan audit LKPP Kementerian Agama mendapatkan penurunan opini di Tahun 2015, BPK-RI menemukan beberapa kelemahan terkait dengan pelaksanaan yaitu Laporan Operasional dengan belanja di Laporan Realisasi Anggaran dan akun-akun terkait sebesar Rp 754,27 miliar pada Kementerian Agama yang tidak dapat dijelaskan. Penyajian beban tersebut belum sepenuhnya mendasarkan pada transaksi jurnal yang lazim dan didukung dengan dokumen yang cukup. Pemerintah Pusat belum sepenuhnya memiliki sistem pengendalian dan pencatatan yang memadai atas penambahan dan/atau pengurangan nilai ekuitas dikarenakan Sistem Akuntansi Pemerintah Pusat tidak mengatur penyusunan LPE pada Akuntansi Pusat sehingga transaksi antar entitas pada LPE Pemerintah Pusat secara sistem akuntansi tidak dapat saling mengeliminasi dan kekurangcermatan KL selaku penyusun LKKL, BA BUN selaku penyusun LK BA BUN, dan DJPB selaku penyusun LKPP dalam melakukan analisis antar laporan keuangan. Sebagai akibatnya, BPK tidak dapat menentukan apakah diperlukan penyesuaian terhadap angka tersebut di atas (BPK, RI, 2016).

\section{Telaah Teori dan Pengembangan Hipotesis}

\section{Pengaruh Sistem Pengendalian Internal Terhadap Kualitas Laporan Keuangan}

Laporan Keuangan Pemerintah dapat dikatakan berkualitas apabila mengandung karakteristik yang telah ditetapkan, sehingga informasi yang dihasilkan dapat menjadi dasar pembuatan keputusan bagi penggunanya. Sistem pengendalian internal merupakan suatu proses yang integral yang dilakukan terus menerus oleh eksekutif dan seluruh pegawai untuk memberikan keyakinan yang memadai atas tercapainya tujuan organisasi.Penelitian sebelumnya yang berkaitan dengan uraian di atas telah dilakukan penelitian yang bersumber dari Udiyanti, dkk (2014) menerangkan bahwa Sistem Pengendalian Internal memiliki pengaruh positif dan signifikan terhadap kualitas laporan keuangan. Hal ini berarti semakin tinggi tingkat penerapan sistem pengendalian internal, maka akan semakin tinggi kualitas laporan keuangan pemerintah daerah kabupaten Buleleng. Pradono \& Basukianto (2015) berkesimpulan bahwa semakin baik sistem pengendalian internal maka semakin baik kualitas laporan keuangan Satuan Kerja Pemerintah Daerah, hal ini disebabkan oleh, Nilai t hitung Sistem Pengendalian Internal sebesar 5,059 dengan signifikansi sebesar 0,000 $(<0,05)$. Dengan demikian terbukti secara statistik bahwa Sistem Pengendalian Internal mempunyai pengaruh positif dan signifikan terhadap Kualitas Laporan Keuangan.

Penelitian Nagor, dkk (2015) menyatakan bahwa Penerapan Sistem Pengendalian Intern berpengaruh terhadap Kualitas Laporan Keuangan Daerah Kabupaten Aceh Barat. Penelitian oleh Kiranayanti \& Erawati (2016) menyebutkan Sistem Pengendalian Intern berpengaruh positif signifikan terhadap kualitas laporan keuangan daerah dengan koefisien variabel Sistem Pengendalian Intern. Hasil penelitian ini menunjukkan semakin tinggi penerapan Sistem Pengendalian Intern, maka semakin tinggi pula pengaruhnya terhadap kualitas laporan keuangan. Evicahyani \& Setiawina (2016) dalam penelitiannya berkesimpulan bahwa Penerapan Sistem Pengendalian Internal Pemerintah memiliki 
pengaruh positif dan signifikan terhadap peningkatan kualitas Laporan Keuangan Pemerintah Daerah Kabupaten Tabanan dengan koefisien regresi 0,229. Ini berarti adanya upaya perbaikan kualitas Laporan Keuangan Pemerintah Daerah melalui penerapan Sistem Pengendalian Internal Pemerintah. Dengan kata lain kualitas laporan keuangan ditentukan oleh kuat lemahnya Sistem Pengendalian Internal Pemerintah yang dimiliki. Ini dibuktikan dari indikator penerapan Sistem Pengendalian Internal Pemerintah (integritas data ketepatan posting dan input data, prosedur otorisasi dokumen transaksi, tersimpannya dokumen sumber data, dan pembagian tanggung jawab) memiliki skor rataan diatas 4. Ini menunjukkan bahwa penerapan Sistem Pengendalian Internal Pemerintah mempunyai kontribusi yang besar terhadap kualitas Laporan Keuangan Pemerintah Daerah Kabupaten Tabanan.

Penelitian yang mendukung lainnya bersumber dari Widari \& Sutrisno (2017) yakni Sistem Pengendalian Internal Pemerintah memiliki pengaruh positif terhadap kualitas laporan keuangan pemerintah daerah Kota Sukabumi, artinya semakin tinggi tingkat penerapan sistem pengendalian pemerintah, maka akan semakin tinggi kualitas laporan keuangan pemerintah daerah. Dengan demikian, dapat dikemukakan hipotesis sebagai berikut:

H1: sistem pengendalian internal berpengaruh positif terhadap kualitas laporan keuangan.

\section{Pengaruh sistem akuntansi instansi terhadap kualitas laporan keuangan}

Definisi kualitas Sistem Akuntansi Instansi mengacu pada tingkat di mana seseorang pemakai sistem akuntansi merasa terpuaskan oleh output (informasi) yang dihasilkan oleh suatu sistem informasi formal. Sedangkan persepsi manfaat Sistem Akuntansi Instansi merupakan sikap yang akan mempengaruhi perilaku (behaviour) seseorang termasuk kinerja seseorang yang menggunakan Sistem Akuntansi Instansi. Persepsi kegunaan sistem akuntansi yang dimaksud adalah tingkat di mana seseorang yakin bahwa menggunakan Sistem Akuntansi Instansi akan meningkatkan pertanggungjawaban laporan keuangan.

Apabila seseorang menganggap bahwa Sistem Akuntansi Instansi yang ada bermanfaat bagi pertanggungjawaban laporan keuangan, maka hal ini akan mempengaruhi perilakunya untuk menggunakan Sistem Akuntansi Instansi yang ada, akan tetapi sebaliknya apabila dia menganggap bahwa Sistem Akuntansi Instansi yang ada tidak ada gunanya, maka dia tidak akan menggunakan Sistem Akuntansi Instansi tersebut.

Hal ini didukung oleh penelitian terdahulu yakni Ponamon (2014) menyatakan bahwa Pemahaman Sistem Akuntansi Keuangan berpengaruh terhadap Kualitas Informasi Laporan Keuanga. Hal ini berarti bahwa pegawai bagian akuntansi/keuangan pada Satua Kerja Pemerintah Daerah Kota Manado telah memahami proses akuntansi sampai menjadi laporan keuangan sehingga tujuan untuk membuat laporan keuangan yang berkualitas dapat tercapai. Hasil penelitian Wati, dkk (2014) menjelaskan bahwa sistem akuntansi keuangan daerah berpengaruh positif dan signifikan terhadap kualitas laporan keuangan daerah. Hal ini berarti semakain tinggi tingkat penerapan sistem akuntansi keuangan daerah, maka akan meningkatkan kualitas laporan keuangan daerah.

Patra, dkk (2015) berkesimpulan bahwa berdasarkan hasil penelitian yang telah dilakukan pada dinas kehutanan kabupaten luwu, provinsi sul-sel, dapat disimpulkan bahwa secara keseluruhan sistem akuntansi keuangan pemerintah daerah di dinas kehutanan kabupaten luwu termasuk kategori sangat baik. Rahayu, dkk (2015) menyebutkan Sistem Akuntansi Keuangan Daerah (SAKD) memiliki pengaruh yang signifikan terhadap Kualitas Laporan Keuangan Daerah kota Pekanbaru. Penelitian sebelumnya dari Nagor, dkk (2015) menyatakan prinsip Pengelolaan Keuangan Daerah berpengaruh terhadap Kualitas Laporan 
Keuangan Daerah. Kiranayanti \& Erawati (2016) berkesimpulan bahwa semakin tinggi penerapan Sistem Pengendalian Intern, maka semakin tinggi pula pengaruhnya terhadap kualitas laporan keuangan Pemerintah Kabupaten Badung.

Penelitian Evicahyani \& Setiawina (2016) berkesimpulan Hasil penelitian ini menunjukkan bahwa pemanfaatan Sistem Informasi Pengelolaan Keuangan Daerah memiliki pengaruh positif dan signifikan terhadap peningkatan kualitas Laporan Keuangan Pemerintah Daerah Kabupaten Tabanan dengan koefisien regresi 0,339. Ini berarti adanya upaya perbaikan kualitas Laporan Keuangan Pemerintah Daerah melalui pemanfaatan Sistem Informasi Pengelolaan Keuangan Daerah. Dengan kata lain kualitas laporan keuangan yang dihasilkan sangat dibantu oleh sistem informasi yang dimiliki dalam pengelolaan keuangan dan dalam pelaporan/penyusunan laporan keuangan. Wijayanti dan Handayani (2017), hasil penelitiannya menyatakan hasil penelitian ini menyatakan bahwa implementasi akuntansi berbasis akrual berpengaruh positif terhadap kualitas laporan keuangan daerah pada Pemerintah Kabupaten Madiun. Hal ini mengindikasikan bahwa ketika implementasi akuntansi berbasis akural semakin baik, maka semakin berkualitas juga laporan keuangan daerah yang dihasilkan. Dengan demikian, dapat dikemukakan hpotesis sebagai berikut:

$\mathrm{H} 2$ : sistem akuntansi instansi berpengaruh positif terhadap kualitas laporan keuangan

\section{Pengaruh kompetensi sumber daya manusia terhadap kualitas laporan keuangan}

Keputusan Kepala Badan Kepegawaian Negara RI Nomor 46A Tahun 2003 tentang Pedoman Penyusunan Standar Kompetensi Jabatan Struktural Pegawai Negeri Sipil menyatakan bahwa kompetensi sumber daya manusia adalah sebagai berikut: "Kemampuan dan karakteristik yang dimiliki oleh seorang Pegawai Negeri Sipil berupa pengetahuan, keterampilan, dan sikap perilaku yang diperlukan dalam pelaksanaan tugas jabatannya, sehingga Pegawai Negeri Sipil tersebut dapat melaksanakan tugasnya secara profesional, efektif dan efisien".

Penelitianyangberkaitandengankompetensi sumber daya manusia berpengaruh terhadap laporan keuangan dilakukan oleh Wati, dkk (2014) menyebutkan bahwa kompetensi sumber daya manusia berpengaruh positif dan signifikan terhadap kualitas laporan keuangan daerah. Hal ini berarti semakain baik kompetensi sumber daya manusia, maka akan meningkatkan kualitas laporan keuangan daerah. Udiyanti, dkk (2014), hasil penelitiannya menyatakan Kompetensi staf akuntansi memiliki pengaruh positif dan signifikan terhadap kualitas laporan keuangan. Hal ini berarti semakin semakin tinggi tingkat kompetensi yang dimiliki staf akuntansi, maka akan semakin tinggi kualitas laporan keuangan pemerintah daerah kabupaten Buleleng. Pradono \& Basukianto (2015) menjelaskan semakin baik kompetensi sumber daya manusia maka semakin baik kualitas laporan keuangan Satuan Kerja Pemerintah Daerah. Rahayu, dkk (2015), hasil penelitiannya mengemukakan bahwa Kompetensi Sumber Daya Manusia memiliki pengaruh yang signifikan terhadap Kualitas Laporan Keuangan Daerah kota Pekanbaru.

Kiranayanti \& Erawati (2016) berkesimpulan bahwa Kompetensi Sumber Daya Manusia berpengaruh positif signifikan terhadap kualitas laporan keuangan daerah dengan koefisien variabel Sumber Daya Manusia. Hasil penelitian ini menunjukkan semakin tinggi kompetensi Sumber Daya Manusia, maka semakin tinggi pula pengaruhnya terhadap kualitas laporan keuangan Kabupaten Badung. Penelitian sebelumnya dari Kurniawan (2016) menjelaskan kompetensi sumber daya manusia yang diproksikan dengan penempatan karyawan sesuai dengan skill, masa kerja karyawan, serta pemberian tanggung jawab terhadap karyawan menjadi indikator membentuk dan mempunyai pengaruh terhadap kualitas laporan keuangan pemerintah daerah. Setyowati, dkk 
(2016) mengemukakan hasil penelitian bahwa Kompetensi sumber daya manusia mempunyai pengaruh positif dan signifikan terhadap peningkatan kualitas Laporan Keuangan Pemerintah Daerah Kota Semarang.

Penelitian Evicahyani \& Setiawina (2016) berkesimpulan bahwa kompetensi Sumber Daya Manusia berpengaruh positif dan signifikan terhadap kualitas Laporan Keuangan Pemerintah Daerah Kabupaten Tabanan dengan koefisien regresi 0,151 . Hasil ini menunjukkan bahwa kompetensi Sumber Daya Manusia yang diwakili oleh responden menentukan kualitas Laporan Keuangan Pemerintah Daerah yang dihasilkan yang akan mempengaruhi pemberian opini oleh BPK-RI. Sebagian besar dari indikator kompetensi Sumber Daya Manusia (latar belakang pendidikan, pemahaman terhadap peraturan dan standar, pelatihan dan bimtek, serta pengalaman bekerja) memiliki rata-rata skor diatas 4 . Ini menandakan bahwa kompetensi Sumber Daya Manusia untuk dapat meningkatkan kualitas Laporan Keuangan Pemerintah Daerah memiliki tingkat yang tinggi. Sari \& Tamrin (2017) menemukan hasil bahwa Kompetensi Sumber Daya Manusia berpengaruh signifikan terhadap Kualitas Informasi Laporan Keuangan pada Badan Pengelola Keuangan dan Aset Daerah Kota Kendari. Dengan demikian, dapat dikemukakan hpotesis sebagai berikut:

H3: kompetensi sumber daya manusia berpengaruh positif terhadap kualitas laporan keuangan.

\section{Metode Penelitian}

Rancangan penelitian yang akan digunakan untuk menganalisis penelitian mengenai "analisis pengaruh sistem pengendalian internal, sistem akuntansi instansi, kompetensi sumber daya manusia dan kualitas laporan keuangan (survey pada Kementerian Agama Provinsi Banten)" adalah tipe penelitian penjelasan (explanatory / confirmatory research), karena penelitian ini bermaksud untuk menjelaskan hubungan kausal antara variabel-variabel dengan melalui pengujian hipotesis yang telah dirumuskan sebelumnya.

Jenis data yang digunakan dalam penelitian ini adalah data primer, yaitu data yang diperoleh secara langsung dari obyek yang telah ditentukan. Sumber data yang diperoleh bersumber dari jawaban responden atas pernyataan kuisioner yang diisi oleh pegawai pada kementerian agama provinsi banten berhubungan dengan pengaruh sistem pengendalian internal, sistem akuntansi instansi dan kompetensi sumber daya manusia terhadap kualitas laporan keuangan.

Data yang diperoleh dari kuisioner merupakan data kualitatif yang dinyatakan dengan angka menjadi data kuantitatif. Data kuantitatif ini berguna untuk input data penelitian hipotesis. Populasi dari penelitian ini adalah staf perencana keuangan, pengelola keuangan dan penyusun laporan keuangan yang berkerja pada Kementerian Agama Provinsi Banten, yang meliputi kantor wilayah Kementerian Agama Provinsi Banten, kantor Kementerian Agama Kabupaten Serang, kantor Kementerian Agama Kabupaten Pandeglang, kantor Kementerian Agama Kabupaten Lebak, kantor Kementerian Agama Kabupaten Tangerang, kantor Kementerian Agama Kota Tangerang, kantor Kementerian Agama Kota Cilegon, kantor Kementerian Agama Kota Serang dan kantor Kementerian Agama Kota Tangerang Selatan terdiri dari bidang pendidikan madrasah, bidang pendidikan agama dan keagamaan islam, bidang urusan agama islam dan bimbingan syariah, bidang penerangan agama islam, zakat dan wakaf, bimbingan masyarakat kristen, bimbingan agama katolik, bimbingan agama hindu, bimbingan agama budha, bidang penyelenggaraan haji dan umrah, sub bagian kepegawaian dan ortala, sub bagian keuangan dan perencanaan, sub bagian hubungan masyarakat, sub bagian umum, sub bagian kerukunan umat beragama, madrasah tsanawiyah negeri serta madrasah aliyah negeri. Ini dijadikan sebagai responden dalam penelitian ini karena berperan penting dalam meningkatkan penilaian terhadap kualitas 
laporan keuangan Kementerian Agama Provinsi Banten. Data penelitian ini dikumpulkan dengan cara mengirim kuesioner ke responden secara langsung. Sampel yang dipilih untuk menjadi bahan penelitian ialah staf perencana keuangan, pengelola keuangan dan penyusun laporan keuangan pada Kementerian Agama Provinsi Banten.

Tabel 2. Definisi Operasional Variabel

\begin{tabular}{|c|c|c|c|c|}
\hline No & Variabel & Dimensi & Indikator & $\begin{array}{c}\text { Skala } \\
\text { Pengukuran }\end{array}$ \\
\hline 1 & $\begin{array}{l}\text { Kualitas } \\
\text { Laporan } \\
\text { Keuangan }\end{array}$ & $\begin{array}{l}\text { Memiliki manfaat } \\
\text { umpan balik } \\
\text { (feedback value) } \\
\text { Memiliki manfaat } \\
\text { prediktif (predictive } \\
\text { value) } \\
\text { Tepat waktu } \\
\text { Lengkap } \\
\text { Penyajian jujur } \\
\text { Dapat diverifikasi } \\
\text { (verifiability) } \\
\text { Netralitas } \\
\text { Dapat dibandingkan } \\
\text { Dapat dipahami }\end{array}$ & $\begin{array}{l}\text { laporan keuangan yang disusun } \\
\text { memiliki manfaat bagi perbaikan } \\
\text { kegiatan selanjutnya. } \\
\text { laporan keuangan yang disusun } \\
\text { mampu memprediksi kemungkinan } \\
\text { pengorganisasi kegiatan dan alokasi } \\
\text { anggaran yang digunakan } \\
\text { laporan keuangan yang disusun dapat } \\
\text { diselesaikan sesuai dengan alokasi } \\
\text { waktu yang telah ditetapkan } \\
\text { laporan keuangan yang disusun } \\
\text { disajikan secara lengkap dengan } \\
\text { memberikan semua informasi yang } \\
\text { memang diperlukan } \\
\text { laporan keuangan yang disusun } \\
\text { merupakan kondisi objektif setiap } \\
\text { penggunaan anggaran maupun } \\
\text { alokasinya } \\
\text { laporan keuangan yang disusun } \\
\text { memberikan ruang untuk verifikasi } \\
\text { atas kemungkinan adanya } \\
\text { penyimpangan } \\
\text { laporan keuangan yang disusun } \\
\text { menerapkan asas netralitas atau } \\
\text { tidak memiliki pretensi untuk } \\
\text { menguntungkan pihak tertentu } \\
\text { laporan keuangan yang disusun } \\
\text { dapat dibandingkan dengan laporan } \\
\text { keuangan periode sebelumnya } \\
\text { laporan keuangan yang disusun } \\
\text { memberikan informasi keuangan atau } \\
\text { laporan yang mudah dipahami }\end{array}$ & Interval \\
\hline
\end{tabular}


2 Sistem Standard Operating

ketersediaan SOP yang formal dan

Interval

\section{Pengendalian}

Internal

3 Sistem

Akuntansi

Instansi

Procedure (SOP)
Pemisahan
wewenang
Dokumen dan
catatan yang
memadai
Tindakan disiplin
atas pelanggaran
Pembatasan akses
Langkah-langkah
pencegahan
kerusakan

Kegiatan

pengidentifikasian

dan pengukuran

dalam bentuk bukti

transaksi dan bukti

pencatatan.

Memindahbukukan

(posting) dari

jurnal berdasarkan

kelompok atau

jenisnya ke dalam

akun buku besar

Penyusunan neraca

saldo berdasarkan

akun buku besar

pada akhir periode

akuntansi

Pelaporan telah ditaati secara optimal

pengakuan realisasi belanja telah

memperhatikan cut off

kerangka kerja dalam melaksanakan

perencanaan kegiatan telah memadai

pendelegasian wewenang dan

tanggung jawab telah dilakukan

dengan tepat

pelaksanaan anggaran telah berjalan

sesuai dengan perencanaan

pengendalian fisik atas aset dalam

pencatatatnnya cukup terkendali

menyediakan dan memanfaatkan

berbagai bentuk dan sarana

komunikasi serta mengelola, mengembangkan dan memperbarui

sistem informasi secara terus

menerus

catatan atas laporan keuangan

telah memberikan informasi yang

memadai

sistem akuntansi instansi (SAI) di

tempat saya bekerja merupakan

sistem yang mudah digunakan

saat menerapkan sistem akuntansi

instansi (SAI) para operator di tempat

saya bekerja sudah menjalankan

prosedur yang ditetapkan seperti

menjalankan rekonsiliasi tepat pada

waktunya

di tempat saya bekerja rekonsiliasi

internal antara SAK dan SIMAK-

BMN dilakukan dengan tepat waktu sistem akuntansi instansi (SAI) di tempat saya bekerja sudah menggunakan sistem yang up date sistem akuntansi instansi sangat menunjang dalam penyusunan laporan keuangan
Interval

Interval 
$4 \quad$ Kompetensi Sumber Daya Manusia

Latar belakang
pendidikan
Uraian peran dan
fungsi
Peran dan tanggung
jawab
Fungsi akuntansi
Sumber daya
pendukung
operasional
Pelatihan keahlian
dalam tugas

pegawai memahami ilmu akuntansi maupun ilmu terkait akuntansi lainnya dalam mendukung pekerjaan pegawai mengetahui kegiatan sektor publik dan metode pengorganisasian kegiatan bersangkutan seseorang yang memiliki keahlian dibidang tertentu seperti hal penyusunan anggaran, pelaksanaan anggaran dan pelaporan, akan terampil mengerjakan pekerjaan dengan mudah, cepat, intuisi dan sangat jarang membuat kesalahan sosialisasi atas peraturan dan standar operasional prosedur di bidang perencanaan, pelaksanaan dan pelaporan anggaran baik yang dikeluarkan oleh Kementerian/ Lembaga yang bersangkutan maupun Kementerian/Lembaga lain yang berkaitan penting agar pegawai dapat memahami peraturan dan standar operasional prsedur tersebut penggunaan aplikasi perencanaan sampai dengan penyusunan laporan telah terimplementasi dengan baik jenjang pembagian tugas staf dan pejabat dalam pengelolaan keuangan dan penyusunan laporan keuangan jelas penempatan pegawai sesuai dengan bidang dan keahliannya dalam rangka mendukung pekerjaan pendidikan dan pelatihan akuntansi bagi pengelola keuangan dan penyusun laporan keuangan pemantapan kompetensi SDM dilakukan secara berkesinambungan penempatan pegawai sesuai dengan bidang dan keahliannya dalam rangka mendukung pekerjaan
Teknis analisis data dilakukan dengan uji regresi berganda. Pengujian regresi berganda dilakukan setelah uji validitas dan uji reliabilitas serta uji asumsi klasik yang terdiri dari uji normalitas, uji multikolinieritas, dan uji heterokedastisitas. Uji validitas dilakukan dengan uji korelasi Pearson, momen antara masing-masing skor indikator dengan total skor 
konstruk. Suatu butir pertanyaan dikatakan valid jika nilai korelasi item butir dengan skor total signifikan pada tingkat signifikansi 0,01 dan 0,02 . Uji reliabilitas menggunkan uji statistik Cronbach Alpha ( $\alpha$ ). Uji normalitias dilakukan dengan Uji Kolmogorof-Smirnov (Uji K-S). Uji multikolinieritas dilakukan dengan melihat angka VIF (Variance Inflation Factor). Uji heterokedastisitas menggunakan uji Glesjer.

Analisis deskriptif digunakan mendeskripsi variabel. Uji t digunakan untuk menguji masingmasing variabel antara sistem pengendalian internal, sistem akuntansi instansi dan kompetensi sumber daya manusia terhadap kualitas laporan keuangan. uji koefisien determinasi (Adjusted $R$ Square) digunakan untuk mengukur seberapa jauh kemampuan model dalam menerangkan variasi variabel dependen pengujian hipotesis 1 sampai dengan hipotesis 3 dilakukan dengan melihat hasil uji-t menunjukkan nilai signifikansi $<0,05$ (pada $\alpha=5 \%$ ) maka hipotesis penelitian terbukti (H0 ditolak H1 diterima).

\section{Analisis Hasil dan Pembahasan}

Penelitian ini bertujuan untuk Menganalisis dan memberikan bukti empiris bahwa sistem pengendalian internal berpengaruh signifikan terhadap kualitas informasi laporan keuangan, menganalisis dan memberikan bukti empiris bahwa sistem akuntansi instansi berpengaruh signifikan terhadap kualitas informasi laporan keuangan, menganalisis dan memberikan bukti empiris bahwa kompetensi sumber daya manusia berpengaruh signifikan terhadap kualitas informasi laporan keuangan. sampel dianalisis sejumlah 95 orang yang terdiri dari 83 orang pengelola keuangan, 4 orang penyusun laporan keuangan dan 8 orang staf perencana keuangan. dari hasil pengujian setiap item indikator instrumen untuk kualitas laporan keuangan tersebut valid. hasil perhitungan uji reliabilitas menunjukkan bahwa nilai Cronbach Alpha $(\alpha)$ untuk masing-masing variabel adalah lebih besar dari 0,60, dengan demikian dapat disimpulkan bahwa item-item instrumen untuk masing-masing variabel adalah reliable.

Hasil uji asumsi klasik menunjukkan distribusi nilai residual variabel adalah normal $(0,650>0,05)$ hasil uji multikolinearitas menunjukkan semua nilai variabel memiliki nilai variance inflation factor $<10$. Hasil uji gletsjer menunjukkan nilai signifikansi $>0,05$ untuk seluruh pengaruh variabel independen terhadap nilai absolut residualnya. Deskripsi variabel dirangkum pada tabel berikut:

Tabel 3. Deskripsi variabel penelitian

\begin{tabular}{llrrrr}
\hline No & \multicolumn{1}{c}{ Variabel } & $\begin{array}{c}\text { Nilai Rata- } \\
\text { Rata }\end{array}$ & $\begin{array}{c}\text { Standar } \\
\text { Deviasi }\end{array}$ & Minimum & Maksimum \\
\hline 1 & Laporan Keuangan & 4,136 & 0,685 & 0,279 & 0,866 \\
2 & Standar Pengendalian Internal & 3,902 & 0,634 & 0,053 & 0,645 \\
3 & Sistem Akuntansi Internal & 3,938 & 0,759 & 0,396 & 0,718 \\
4 & Sumber Daya Manusia & 3,981 & 0,706 & 0,317 & 0,751 \\
\hline
\end{tabular}

Hasil pengujian model penelitian dan hipotesis terangkum pada tabel berikut. 
Tabel 4. Rangkuman hasil pengujian

\begin{tabular}{lcccc}
\hline Keterangan & B & Std. Error & t-hitung & Sig. \\
\hline Sistem Pengendalian Internal & 0,283 & 0,114 & 2,480 & 0,015 \\
Sistem Akuntansi Instansi & 0,327 & 0,087 & 3,763 & 0,000 \\
Sumber Daya Manusia & 0,275 & 0,108 & 2,551 & 0,012 \\
Constant & 0,647 & 0,244 & 0,264 & 0,010 \\
R-Square & 0,710 & & & \\
Adjusted R-Square & 0,701 & & & \\
F-hitung & 74,311 & & & \\
Sig. F & 0,000 & & & \\
\hline
\end{tabular}

Berdasarkan tabel diatas, dapat digambarkan hasil persamaan regresi penelitian ini adalah sebagai berikut: $\mathrm{Y}=\mathbf{0 , 6 4 7}+\mathbf{0 , 2 8 3} \mathrm{X} 1+\mathbf{0 , 3 2 7} \mathrm{X} 2+\mathbf{0 , 2 7 5} \mathrm{X3}+\mathrm{e}$

Tabel 5. Ringkasan Hasil Pengujian Hipotesis

\begin{tabular}{clc}
\hline Kode & \multicolumn{1}{c}{ Hipotesis } & Hasil \\
\hline H1 & $\begin{array}{l}\text { Sistem pengendalian internal berpengaruh positif terhadap kualitas } \\
\text { laporan keuangan }\end{array}$ & Terbukti \\
H2 & $\begin{array}{l}\text { Sistem akuntansi instansi berpengaruh positif terhadap kualitas laporan } \\
\text { keuangan }\end{array}$ & Terbukti \\
H3 & $\begin{array}{l}\text { Kompetensi sumber daya manusia berpengaruh positif terhadap kualitas } \\
\text { laporan keuangan }\end{array}$ & Terbukti \\
\hline
\end{tabular}

\section{Pengaruh sistem pengendalian internal} terhadap kualitas laporan keuangan

Hipotesis pertama menyatakan bahwa sistem pengendalian internal berpengaruh signifikan terhadap kualitas laporan keuangan. Hasil pengujian statistik menunjukkan bahwa nilai koefisien regresi variabel sistem pengendalian internal adalah 0,283 . Nilai ini signifikan pada tingkat signifikansi 0,05 dengan $\mathrm{p}$ value 0,015 . Hal ini menunjukkan bahwa sistem pengendalian internal berpengaruh signifikan terhadap kualitas laporan keuangan.

Hasil pengujian hipotesis ini sejalan dengan pendapat Udiyanti, dkk (2014) menerangkan bahwa Sistem Pengendalian Internal memiliki pengaruh positif dan signifikan terhadap kualitas laporan keuangan. Hal ini berarti semakin tinggi tingkat penerapan sistem pengendalian internal, maka akan semakin tinggi kualitas laporan keuangan pemerintah daerah kabupaten Buleleng. Pradono \& Basukianto (2015) berkesimpulan bahwa semakin baik sistem pengendalian internal maka semakin baik kualitas laporan keuangan Satuan Kerja Pemerintah Daerah, hal ini disebabkan oleh, Nilai $t$ hitung Sistem Pengendalian Internal sebesar 5,059 dengan signifikansi sebesar 0,000 $(<0,05)$.

Dengan demikian terbukti secara statistik bahwa Sistem Pengendalian Internal mempunyai pengaruh positif dan signifikan terhadap Kualitas Laporan Keuangan. Penelitian Nagor, dkk (2015) menyatakan bahwa Penerapan Sistem Pengendalian Intern berpengaruh terhadap Kualitas Laporan Keuangan Daerah Kabupaten Aceh Barat. Penelitian oleh 
Kiranayanti \& Erawati (2016) menyebutkan Sistem Pengendalian Intern berpengaruh positif signifikan terhadap kualitas laporan keuangan daerah dengan koefisien variabel Sistem Pengendalian Intern. Hasil penelitian ini menunjukkan semakin tinggi penerapan Sistem Pengendalian Intern, maka semakin tinggi pula pengaruhnya terhadap kualitas laporan keuangan. Evicahyani \& Setiawina (2016) dalam penelitiannya berkesimpulan bahwa Penerapan Sistem Pengendalian Internal Pemerintah memiliki pengaruh positif dan signifikan terhadap peningkatan kualitas Laporan Keuangan Pemerintah Daerah Kabupaten Tabanan dengan koefisien regresi 0,229.

Ini berarti adanya upaya perbaikan kualitas Laporan Keuangan Pemerintah Daerah melalui penerapan Sistem Pengendalian Internal Pemerintah. Dengan kata lain kualitas laporan keuangan ditentukan oleh kuat lemahnya Sistem Pengendalian Internal Pemerintah yang dimiliki. Ini dibuktikan dari indikator penerapan Sistem Pengendalian Internal Pemerintah (integritas data ketepatan posting dan input data, prosedur otorisasi dokumen transaksi, tersimpannya dokumen sumber data, dan pembagian tanggung jawab) memiliki skor rataan diatas 4 .

Ini menunjukkan bahwa penerapan Sistem Pengendalian Internal Pemerintah mempunyai kontribusi yang besar terhadap kualitas Laporan Keuangan Pemerintah Daerah Kabupaten Tabanan. Penelitian yang mendukung lainnya bersumber dari Widari \& Sutrisno (2017) yakni Sistem Pengendalian Internal Pemerintah memiliki pengaruh positif terhadap kualitas laporan keuangan pemerintah daerah Kota Sukabumi, artinya semakin tinggi tingkat penerapan sistem pengendalian pemerintah, maka akan semakin tinggi kualitas laporan keuangan pemerintah daerah. Hasil tersebut dapat dipahami bahwa untuk meningkatkan kualitas laporan keuangan, sistem pengendalian internal memiliki peran untuk mengakomodir sistem kerja yang dilaksanakan pegawai dalam menentukan hasil dari laporan keuangan. Jika sistem pengendalian internal baik maka akan dengan mudah mendapatkan laporan keuangan yang baik dan sebaliknya jika rendah maka kualitas laporan keuangan yang dihasilkan akan rendah pula.

\section{Pengaruh Sistem Akuntansi Instansi terhadap Kualitas Laporan Keuangan}

Hipotesis kedua menyatakan bahwa sistem akuntansi instansi berpengaruh signifikan terhadap kualitas laporan keuangan. Hasil pengujian statistik menunjukkan bahwa nilai koefisien regresi variabel sistem akuntansi instansi adalah 0,327. Nilai ini signifikan pada tingkat signifikansi 0,05 dengan $p$ value 0,000 . Hal ini menunjukkan bahwa sistem akuntansi instansi berpengaruh signifikan terhadap kualitas laporan keuangan.

Hasil pengujian hipotesis ini sejalan dengan pendapat Ponamon (2014) menyatakan bahwa Pemahaman Sistem Akuntansi Keuangan berpengaruh terhadap Kualitas Informasi Laporan Keuanga. Hal ini berarti bahwa pegawai bagian akuntansi/keuangan pada Satua Kerja Pemerintah Daerah Kota Manado telah memahami proses akuntansi sampai menjadi laporan keuangan sehingga tujuan untuk membuat laporan keuangan yang berkualitas dapat tercapai.

Hasil penelitian Wati, dkk (2014) menjelaskan bahwa sistem akuntansi keuangan daerah berpengaruh positif dan signifikan terhadap kualitas laporan keuangan daerah. Hal ini berarti semakain tinggi tingkat penerapan sistem akuntansi keuangan daerah, maka akan meningkatkan kualitas laporan keuangan daerah. Patra, dkk (2015) berkesimpulan bahwa berdasarkan hasil penelitian yang telah dilakukan pada dinas kehutanan kabupaten luwu, provinsi sul-sel, dapat disimpulkan bahwa secara keseluruhan sistem akuntansi keuangan pemerintah daerah di dinas kehutanan kabupaten luwu termasuk kategori sangat baik.

Rahayu, dkk (2015) menyebutkan Sistem Akuntansi Keuangan Daerah (SAKD) 
memiliki pengaruh yang signifikan terhadap Kualitas Laporan Keuangan Daerah Pekanbaru. Penelitian sebelumnya dari Nagor, dkk (2015) menyatakan prinsip Pengelolaan Keuangan Daerah berpengaruh terhadap Kualitas Laporan Keuangan Daerah. Kiranayanti \& Erawati (2016) berkesimpulan bahwa semakin tinggi penerapan Sistem Pengendalian Intern, maka semakin tinggi pula pengaruhnya terhadap kualitas laporan keuangan Pemerintah Kabupaten Badung.

Penelitian Evicahyani \& Setiawina (2016) berkesimpulan Hasil penelitian ini menunjukkan bahwa pemanfaatan Sistem Informasi Pengelolaan Keuangan Daerah memiliki pengaruh positif dan signifikan terhadap peningkatan kualitas Laporan Keuangan Pemerintah Daerah Kabupaten Tabanan dengan koefisien regresi 0,339 . Ini berarti adanya upaya perbaikan kualitas Laporan Keuangan Pemerintah Daerah melalui pemanfaatan Sistem Informasi Pengelolaan Keuangan Daerah. Dengan kata lain kualitas laporan keuangan yang dihasilkan sangat dibantu oleh sistem informasi yang dimiliki dalam pengelolaan keuangan dan dalam pelaporan/penyusunan laporan keuangan.

Wijayanti dan Handayani (2017), hasil penelitiannya menyatakan hasil penelitian ini menyatakan bahwa implementasi akuntansi berbasis akrual berpengaruh positif terhadap kualitas laporan keuangan daerah pada Pemerintah Kabupaten Madiun. Hal ini mengindikasikan bahwa ketika implementasi akuntansi berbasis akural semakin baik, maka semakin berkualitas juga laporan keuangan daerah yang dihasilkan.

Hasil tersebut dapat dipahami bahwa untuk meningkatkan kualitas laporan keuangan, sistem akuntansi instansi yang dimiliki berpengaruh besar terhadap kualitas laporan keuangan. Jika sistem akuntansi berjalan dengan baik maka kualitas laporan keuangan yang dihasilkan akan baik pula dan sebaliknya jika sistem akuntansi yang diprogram tidak baik maka kualitas laporan keuangan yang dihasilkan akan rendah pula.

\section{Pengaruh Kompetensi Sumber Daya Manusia terhadap Kualitas Laporan Keuangan}

Hipotesis ketiga menyatakan bahwa kompetensi sumber daya manusia berpengaruh signifikan terhadap kualitas laporan keuangan. Hasil pengujian statistik menunjukkan bahwa nilai koefisien regresi variabel kompetensi sumber daya manusi adalah 0,275. Nilai ini signifikan pada tingkat signifikansi 0,05 dengan $\mathrm{p}$ value 0,012 . Hal ini menunjukkan bahwa kompetensi sumber daya manusia berpengaruh signifikan terhadap kualitas laporan keuangan.

Hal ini sejalan dengan yang dikatakan oleh Wati, dkk (2014) menyebutkan bahwa kompetensi sumber daya manusia berpengaruh positif dan signifikan terhadap kualitas laporan keuangan daerah. Hal ini berarti semakain baik kompetensi sumber daya manusia, maka akan meningkatkan kualitas laporan keuangan daerah. Udiyanti, dkk (2014), hasil penelitiannya menyatakan Kompetensi staf akuntansi memiliki pengaruh positif dan signifikan terhadap kualitas laporan keuangan. Hal ini berarti semakin semakin tinggi tingkat kompetensi yang dimiliki staf akuntansi, maka akan semakin tinggi kualitas laporan keuangan pemerintah daerah kabupaten Buleleng.

Pradono \& Basukianto (2015) menjelaskan semakin baik kompetensi sumber daya manusia maka semakin baik kualitas laporan keuangan Satuan Kerja Pemerintah Daerah. Rahayu, dkk (2015), hasil penelitiannya mengemukakan bahwa Kompetensi Sumber Daya Manusia memiliki pengaruh yang signifikan terhadap Kualitas Laporan Keuangan Daerah kota Pekanbaru. Kiranayanti \& Erawati (2016) berkesimpulan bahwa Kompetensi Sumber Daya Manusia berpengaruh positif signifikan terhadap kualitas laporan keuangan daerah dengan koefisien variabel Sumber Daya Manusia. Hasil penelitian ini menunjukkan semakin tinggi kompetensi Sumber Daya Manusia, maka semakin tinggi pula pengaruhnya terhadap kualitas laporan keuangan Kabupaten Badung. 
Penelitian sebelumnya dari Kurniawan (2016) menjelaskan kompetensi sumber daya manusia yang diproksikan dengan penempatan karyawan sesuai dengan skill, masa kerja karyawan, serta pemberian tanggung jawab terhadap karyawan menjadi indikator membentuk dan mempunyai pengaruh terhadap kualitas laporan keuangan pemerintah daerah. Setyowati, dkk (2016) mengemukakan hasil penelitian bahwa Kompetensi sumber daya manusia mempunyai pengaruh positif dan signifikan terhadap peningkatan kualitas Laporan Keuangan Pemerintah Daerah Kota Semarang.

Penelitian Evicahyani \& Setiawina (2016) berkesimpulan bahwa kompetensi Sumber Daya Manusia berpengaruh positif dan signifikan terhadap kualitas Laporan Keuangan Pemerintah Daerah Kabupaten Tabanan dengan koefisien regresi 0,151 . Hasil ini menunjukkan bahwa kompetensi Sumber Daya Manusia yang diwakili oleh responden menentukan kualitas Laporan Keuangan Pemerintah Daerah yang dihasilkan yang akan mempengaruhi pemberian opini oleh BPK-RI. Sebagian besar dari indikator kompetensi Sumber Daya Manusia (latar belakang pendidikan, pemahaman terhadap peraturan dan standar, pelatihan dan bimtek, serta pengalaman bekerja) memiliki rata-rata skor diatas 4 . Ini menandakan bahwa kompetensi Sumber Daya Manusia untuk dapat meningkatkan kualitas Laporan Keuangan Pemerintah Daerah memiliki tingkat yang tinggi.

Sari \& Tamrin (2017) menemukan hasil bahwa Kompetensi Sumber Daya Manusia berpengaruh signifikan terhadap Kualitas Informasi Laporan Keuangan pada Badan Pengelola Keuangan dan Aset Daerah Kota Kendari. Hasil tersebut dapat dipahami bahwa untuk meningkatkan kualitas laporan keuangan, seorang pegawai sangat bergantung pada tingkat kompetensinya. Jika pegawai memiliki kompetensi yang baik maka pegawai akan dengan mudah melakukan tugasnya dalam membuat laporan keuangan dan sebaliknya jika kompetensinya rendah maka pegawai akan mendapatkan kesulitan sehingga kualitas laporan keuangan yang dihasilkan akan rendah pula.

\section{Simpulan, Keterbatasan, dan Implikasi Hasil Penelitian}

Penelitian ini bertujuan untuk mengetahui pengaruh sistem pengendalian internal, sistem akuntansi instansi dan kompetensi sumber daya manusia pada Kementerian Agama Provinsi Banten terhadap kualitas laporan keuangan. Berdasarkan hasil penelitian maka dapat diambil kesimpulan bahwasannya sistem pengendalian internal berpengaruh positif terhadap kualitas laporan keuangan, sehingga semakin baik tingkat sistem pengendalian internalnya, maka akan semakin baik kualitas laporan keuangan yang dibuat. Untuk sistem akuntansi instansi berpengaruh positif terhadap kualitas laporan keuangan, sehingga semakin baik tingkat sistem akuntansi instansi, maka akan semakin baik kualitas laporan keuangan yang dibuat, dan kompetensi sumber daya manusia berpengaruh positif terhadap kualitas laporan keuangan, sehingga semakin baik tingkat kompetensi sumber daya manusia yang terdapat pada Kementerian Agama Provinsi Banten, maka akan semakin baik kualitas laporan keuangan yang dibuat.

Penelitian ini berimplikasi pada pegawai. Adanya pengaruh sistem pengendalian internal, sistem akuntansi instansi dan kompetensi sumber daya manusia terhadap kualitas laporan keuangan yang dilaksanakan oleh pegawai Kementerian Agama Provinsi Banten menunjukkan bahwa penguasaan terhadap metode dan teknik pembuatan laporan keuangan serta segala hal yang menyangkut pemerintahan seperti organisasi, fungsi, program, dan kegiatan pemerintah akan dapat ditunjang oleh sistem bahwa tercapainya tujuan pembuatan laporan keuangan merupakan kebutuhan organisasi Kementerian Agama sekaligus kebutuhan personil pegawai pemerintah. 
Evaluasi atas hasil penelitian ini harus mempertimbangkan keterbatasan yang mungkin mempengaruhi hasil penelitian, di antaranya adalah sulitnya mengendalikan responden. Penelitian selanjutnya dapat menggunakan metode lain atau setidaknya dapat memastikan pihak responden bersedia bekerja sama. Berdasarkan hasil penelitian yang telah dilakukan maka penelitian mendatang sebaiknya melakukan sebuah penelitian dengan menggunakan metode wawancara langsung untuk mengumpulkan data penelitian agar dapat mengurangi adanya kelemahan terkait internal validity. Peneliti juga menyarankan untuk penelitian selanjutnya agar memperluas objek penelitian pada Kementerian Agama, RI, sehingga hasilnya dapat digeneralisasi. Pada penelitian ini, variabel independen yang diteliti berpengaruh terhadap variabel kualitas laporan keuangan sebesar $70,1 \%$, berarti bahwa ada pengaruh sebesar $29,9 \%$ dari variabel-variabel lain di luar model. Penelitian selanjutnya disarankan untuk meneliti pengaruh variabelvariabel lain yang belum termasuk dalam model regresi pada penelitian ini.

\section{Daftar Referensi}

Evicahyani, S. I., \& Setiawina, N. D. (2016). Analisis Faktor-Faktor Yang Mempengaruhi Kualitas Laporan Keuangan Pemerintah Daerah Kabupaten Tabanan. E-Jurnal Ekonomi dan Bisnis Universitas Udayana 5.(3), 403-428.

George, H. B., \& Hopword, W. S. (1995). Sistem Informasi Akuntansi. Edisi Indonesia Terjemahan: Amir Abadi Jusuf dan Rudi M. Tambunan. Jakarta: Salemba Empat.

Kiranayanti, I. A., \& Erawati, N. M. (2016). Pengaruh Sumber Daya Manusia, Sistem Pengendalian Intern, Pemahaman Basis Akrual Terhadap Kualitas Laporan Keuangan Daerah. E-Jurnal Akuntansi, 16(2), 1290-1318.

Kurniawan, I. S. (2016). Determinan Kualitas
Laporan Keuangan Pemerintah Daerah. Kinerja : Jurnal Ekonomi dan Manajemen 13, (1), 47-58.

Mardiasmo. (2006). Perwujudan Transparansi dan Akuntabilitas Publik melalui Akuntansi Sektor Publik: Suatu Sarana Good Governance. Jurnal Akuntansi Pemerintah 2 (1), -.

Nagor, T. F., Darwanis, \& Abdullah, S. (2015). Pengaruh Penerapan Sistem Pengendalian Intern Dan Penerapan Prinsip Pengelolaan Keuangan Daerah Terhadap Kualitas Laporan Keuangan Pemerintah Daerah Kabupaten Aceh Barat. Jurnal Magister Akuntansi Pascasarjana Universitas Syiah Kuala, 72- 79.

Patra, A. D., Bustami, L., \& Hasriani. (2015). Pengaruh Penerapan Sistem Akuntansi Keuangan Pemerintah Daerah Terhadap Kualitas Laporan Keuangan Pemerintah Daerah. Jurnal Akuntansi 02, (01), 1-9.

Ponamon, I. F. (2014). Pengaruh Pengawasan Internal, Pemahaman Sistem Akuntansi Keuangan, dan Kapasitas Sumber Daya Manusia Terhadap Kualitas Informasi Laporan Keuangan Pemerintah Daerah Pada SKPD Pemerintah Kota Manado. Jurnal Riset Akuntansi Going Concern 9(2), 68-80.

Pradono, F. C., \& Basukianto. (2015). Kualitas Laporan Keuangan Pemerintah Daerah: Faktor Yang Mempengaruhi Dan Implikasi Kebijakan (Studi Pada Skpd Pemerintah Provinsi Jawa Tengah). Jurnal Bisnis dan Ekonomi (JBE) 2, (2), 188 - 200.

Rahayu, L., Kennedy, \& Anisma, Y. (2015). Pengaruh Kompetensi Sumber Daya Manusia (SDM), Penerapan Sistem Akuntansi Keuangan Daerah, dan Penerapan Standar Akuntansi Pemerintah (SAP) Terhadap Kualitas Laporan Keuangan Daerah Pada Pemerintah Provinsi Riau (Studi Empiris Pada SKPD Provinsi Riau). Jurnal Online Mahasiswa (JOM) Bidang Ilmu Ekonomi 1 (2), 1-15. 
Roni, M., Hamdani, L., Husnan, \& Fitriah, N. (2015). Determinan Kualitas Laporan Keuangan Satuan Kerja Di Wilayah Pembayaran Kantor Pelayanan Perbendaharaan Negara Mataram. Jurnal Akuntansi Aktual 3 (2), 175-187.

Sari, I. M., \& Tamrin, N. A. (2017). Pengaruh Penerapan Good Government Governance Dan Kompetensi Sumber Daya Manusia Terhadap Kualitas Informasi Laporan Keuangan (Studi Pada Badan Pengelola Keuangan Dan Aset Daerah Kota Kendari). Jurnal Akuntansi Dan Keuangan 1 (1), 106121.

Setyowati, L., Isthika, W., \& Pratiwi, R. D. (2016). Faktor-Faktor Yang Mempengaruhi Kualitas Laporan Keuangan Pemerintah Daerah Kota Semarang. KINERJA 20 (2), 179-191.
Udiyanti, N. L., Atmadja, A. T., \& Darmawan, N. A. (2014). Pengaruh Penerapan Standar Akuntansi Pemerintahan, Sistem Pengendalian Internal, Dan Kompetensi Staf Akuntansi Terhadap Kualitas Laporan Keuangan Pemerintah Daerah (Studi Kasus Pada Skpd Kabupaten Buleleng). JIMAT (Jurnal Ilmiah Mahasiswa Akuntansi 1 (1). Widari, L., dan, \& Sutrisno. (2017). Pengaruh Sistem Pengendalian Internal Pemerintah Dan Komitmen Organisasi Terhadap Kualitas Laporan Keuangan Daerah. Jurnal Ilmiah Ilmu Ekonomi (Jurnal Akuntansi, Pajak dan Manajemen) 5 (10), 117-126.

Wijayanti, R. d. (2017). Pengaruh Kompetensi Sdm Dan Implementasi Akuntansi Akrual Terhadap Kualitas Laporan Keuangan Daerah. Jurnal Ilmu dan Riset Akuntansi, 6(3), - . 